\title{
Variability of Sea Surface Temperature in Indonesia Based on Aqua Modis Satellite Data
}

\author{
Nurul Fatimah Yunita ${ }^{1}$, Muhammad Zikra ${ }^{1}$
}

\begin{abstract}
Sea Surface Temperature (SST) is one of the oceanographic factor in seawater. Its value depends on several factors. In indonesia, SST value depend on season and location. The aims of this study are to analyze the spatial and temporal variability of SST using 10-years (2007-2016) Aqua Modis satellite data. The result shows that the average of SST in Indonesia ranges from $27-31{ }^{\circ} \mathrm{C}$ depending on location. SST in equator area range from $30-31{ }^{\circ} \mathrm{C}$ and in nonequator area range from $27-30^{\circ} \mathrm{C}$. Monthly and seasonal variation of SST also show different value for each area in the indonesian region.
\end{abstract}

Keywords — Sea surface temperature, Indonesia, satellite data, variability.

\section{INTRODUCTION}

$\mathrm{I}^{\mathrm{n}}$ ndonesia is one of the tropical country that has territory

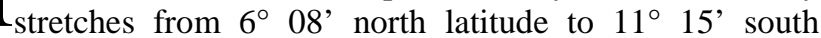
latitude and from $94^{\circ} 45^{\prime}$ to $141^{\circ} 05^{\prime}$ east longitude. Its located between the Pacific and the Indian Ocean, and bridges two continents, Asia and Australia [1]. The consequences of the complexity of topography and connectivity between the Pacific and the Indian Ocean in this region can affect the sea surface temperature. While, the Sea Surface Temperature (SST) play important role in atmospheric state both locally and globally [2].

The characteristics of SST variabilitity in Indonesia generally have largest seasonal cycle which occurs in Timor, Arafura, Banda, and South China Seas. The highest SST variability occurs along and offshores Java and Sumatra coast. The variability of SST also influences by monsoon or season [2].

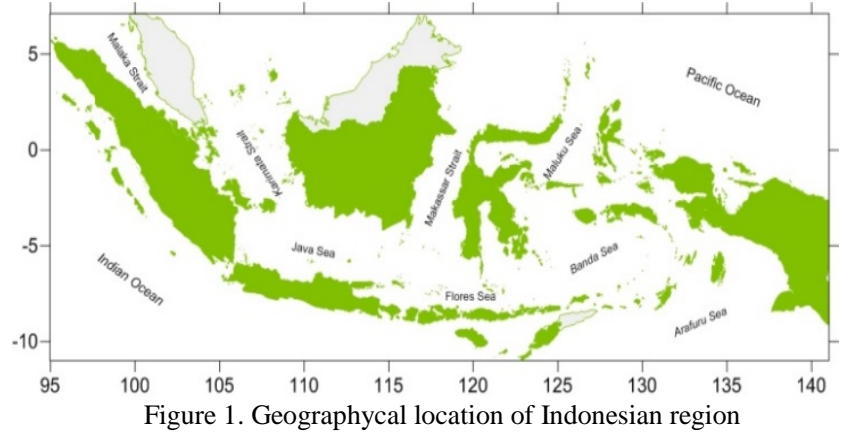

Remote sensing technology is one of the alternative technologies that can be used in monitoring efforts to change the marine environment within a certain period. The advantages gained in the utilization of this technology are the range of wide observations and high temporal resolution. One application of remote sensing technology that is often used is monitoring of sea surface temperature using the Aqua MODIS satellite [3]. The focus of this study

\footnotetext{
${ }^{1}$ Nurul Fatimah Yunita, Muhammad Zikra are with Department of Marine Engineering, Faculty of Marine Technology, Institut Teknologi Sepuluh Nopember, Surabaya, 60111, Indonesia. E-mail: nurulfatimahyunita@gmail.com; mzikro@oe.its.ac.id;
}

was SST data based on satellite measurements for 10 years. The main purpose is to analyze the average temperature of SST as well as its monthly and seasonal variations.

\section{METHOD}

A series of monthly and yearly SST data are derived from the Aqua MODIS level 3 Standard Map Image from NASA (http://oceancolor.gsfc.nasa.gov) was collected from the period of 2007 - 2016 to study SST variability in the Indonesian region. the Aqua MODIS (Moderate Resolution Imaging Spectroradiometer) is designed for the accurate measurement of SST [4]. MODIS has a viewing swath width of 2,330 km, and it images 21 the earth in 36 spectral bands or group of wavelengths, ranging from 405 to 14.385 $\mu \mathrm{m}$ [4]. The data was downloaded in smi fornat and the cropped by using Seadas 7.32 software and convert into text file format. And from this type file, the variation of SST can be measure.

\section{RESULT AND ANALYSIS}

\section{A. Average SST}

The average temperature distribution in Indonesian waters is shown in figure 2. Its value ranges from $27-31{ }^{\circ} \mathrm{C}$ depending on its location. The highest SST value shown in offshore Sumatra which reached $31^{\circ} \mathrm{C}$ and the lowest obtained in Arafura Sea that reached $27^{\circ} \mathrm{C}$. This is caused by Sumatra island located in equator and tend to get more solar radiation.

The SST in west area of Indonesia warmer than east area. SST in west area ranged from $29-31^{\circ} \mathrm{C}$ like in offshores Sumatra and Java Island, Malacca Strait, Karimata Strait, Java Sea, and Makassar Strait. Whereas, east area ranged from $27-29^{\circ} \mathrm{C}$ like in Flores Sea, Banda Sea, Maluku Sea, and the Arafura Sea. 


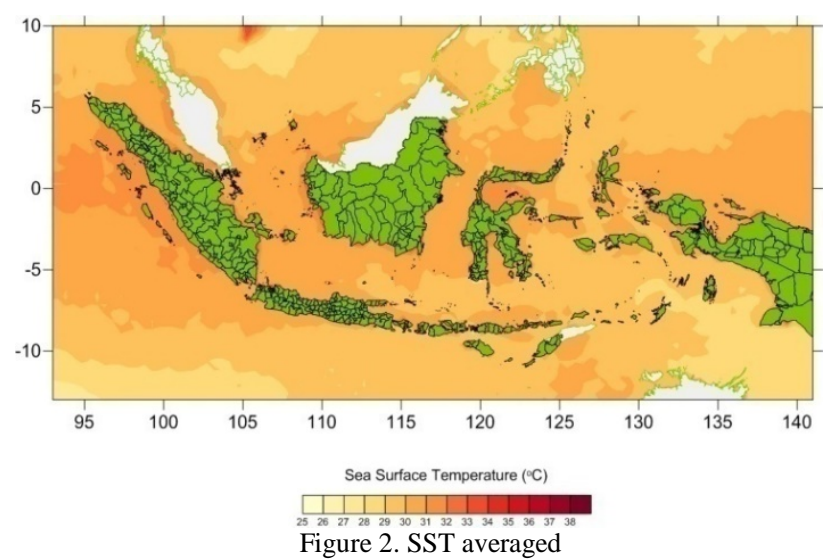

B. Montly and Seasonal Variation

\section{1) West Season}

West season in Indonesia occurs in December - February that shown in figure 3. In this season, SST warmer in the south area which reached $30-31^{\circ} \mathrm{C}$ than north area which reached $28-29^{\circ} \mathrm{C}$. This is can be seen in offshores of Sumatra and Java, Java Timor, Flores, and Banda Seas. Generally, SST in Indonesia in the east season is characterized by higher SST values in regions south of the equator [5][6].

In December, SST move from australian dan pacific region. the highest value in this month seen in Timor and Banda Seas. The temperature of this area is about $32{ }^{\circ} \mathrm{C}$. The Distribution of SST then move toward south of indonesian region for the next month. In January, the SST shown the high value in all over south area. while SST in February shown that the decreasing in a view area such like Banda Sea and Flores Sea. This is because of north monsoon is fully developed in January [7].
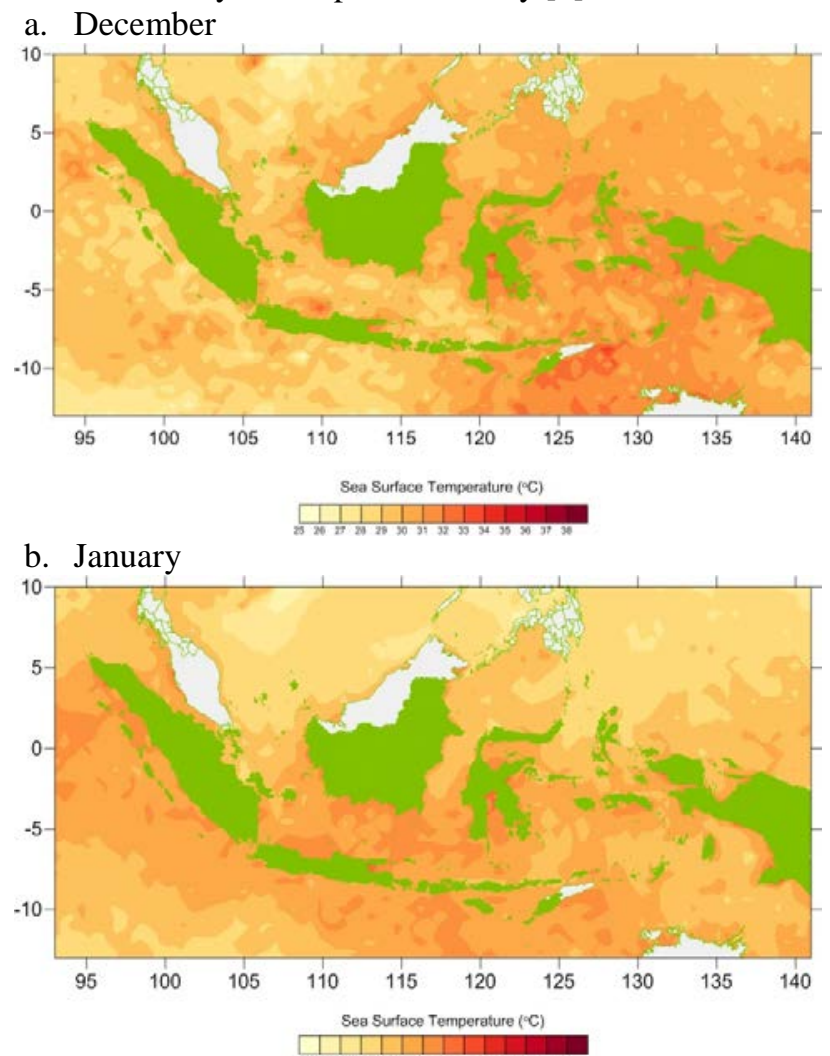

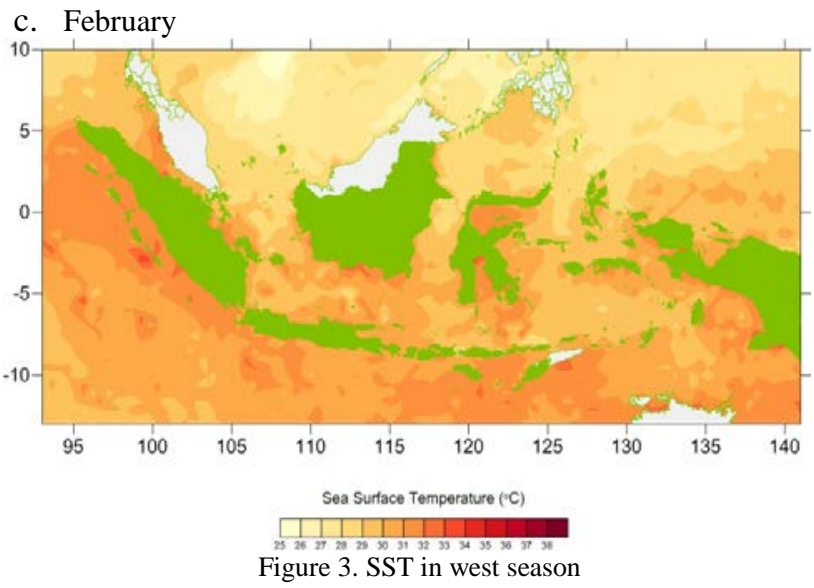

\section{2) East Season}

In the east seasons, the waters in the Northern region such as the Malacca Strait, Karimata Strait, Makassar Strait, Maluku Sea, Northern Papua and some parts of Sumatra show higher temperature than the Southern region. This is illustrated in figure 4. In the east seasons, SST in the Indonesian region is characterized by higher temperatures in the northern region [6], [8]. The lowest value of SST in this season reached $26{ }^{\circ} \mathrm{C}$ in August and the highest value reach $32{ }^{\circ} \mathrm{C}$ in June.

a. June

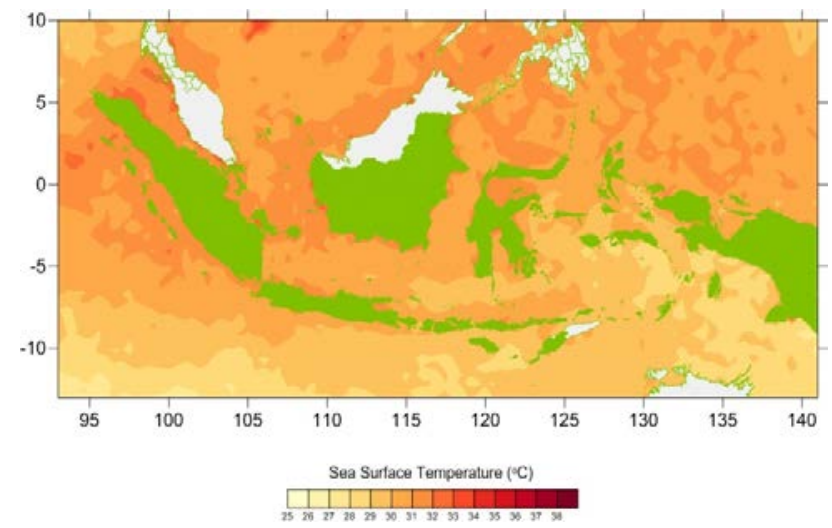

b. July

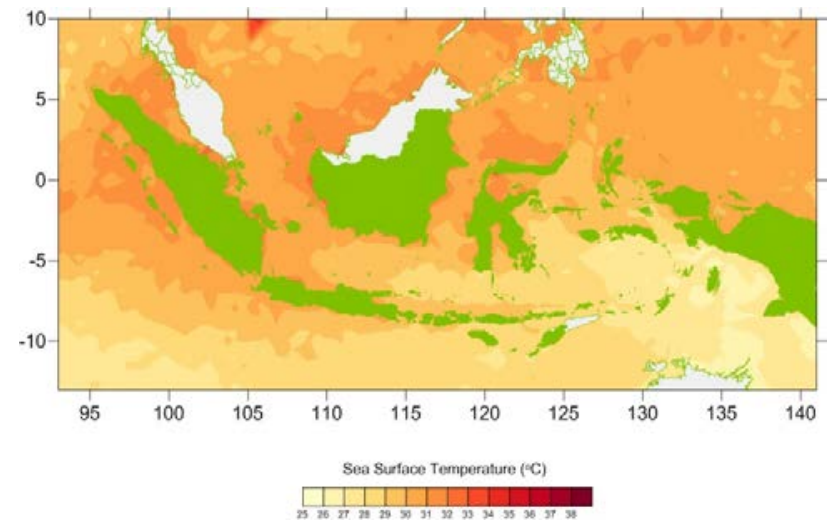




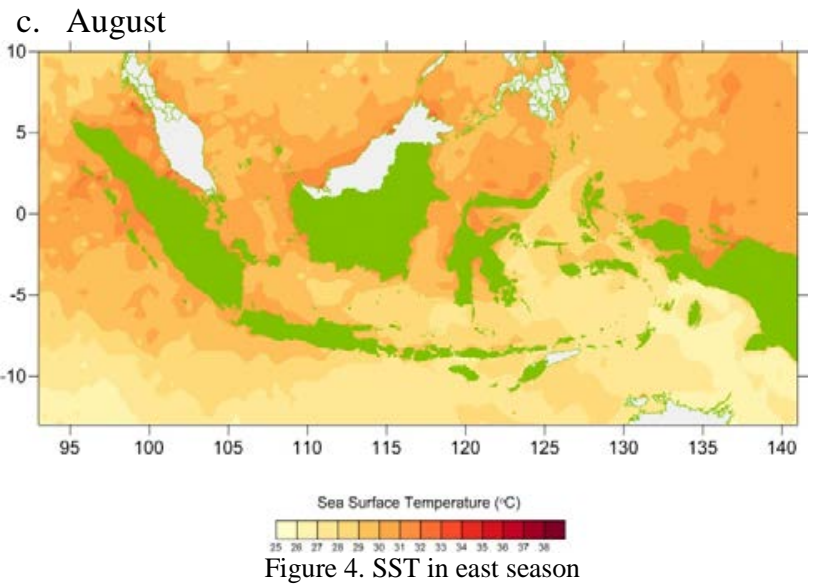

3) The First Transition Season

The first transition season is transition from west season to east season. In the First transitional season shown slowly decreasing value of SST in southern region in each month figure 5. The decreasing of SST in the Southern region has not been too visible by March. Becaus there is influence from the west season. The temperature drops in this region began to be seen in April and will be seen more clearly in May. It is characterized by low temperature in some of the southern waters of Java, Bali, Nusa Tenggara, and the Arafura Sea. The highest temperature this season can reached $32{ }^{\circ} \mathrm{C}$ which occurred in February. While the lowest temperature could reach $27^{\circ} \mathrm{C}$.
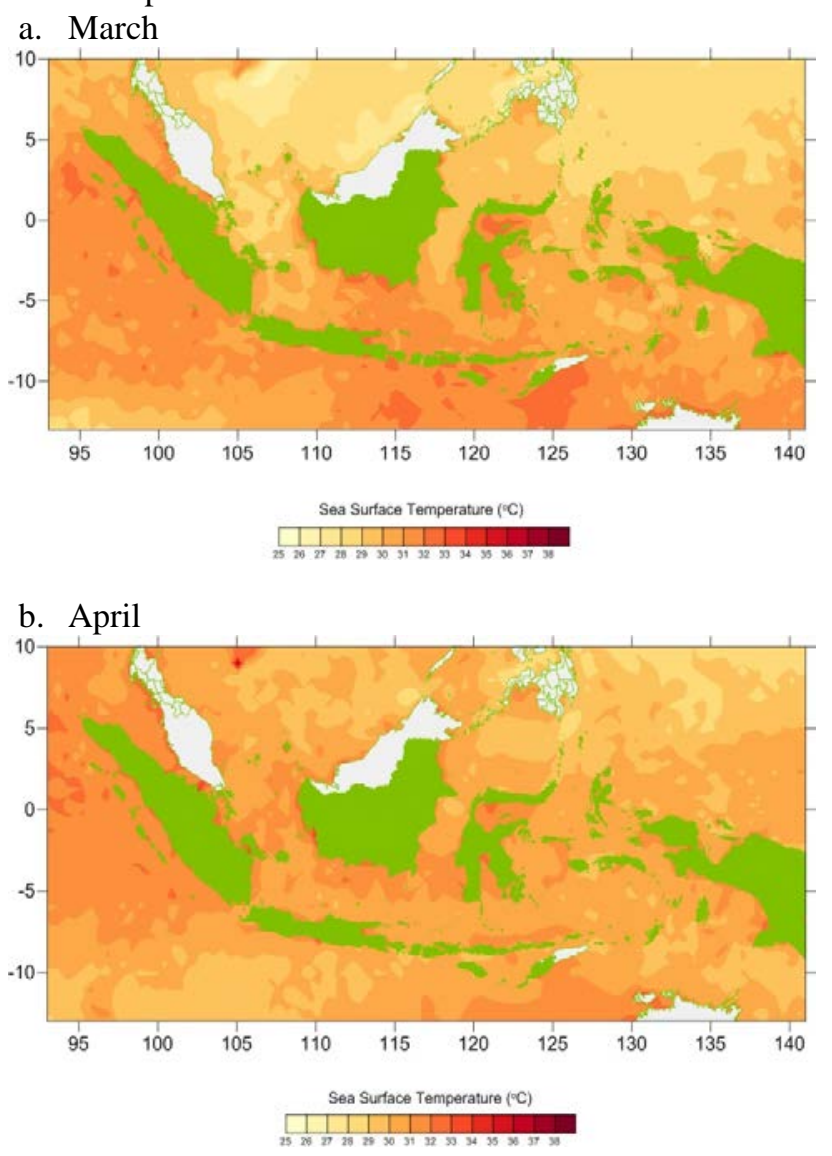

c. May

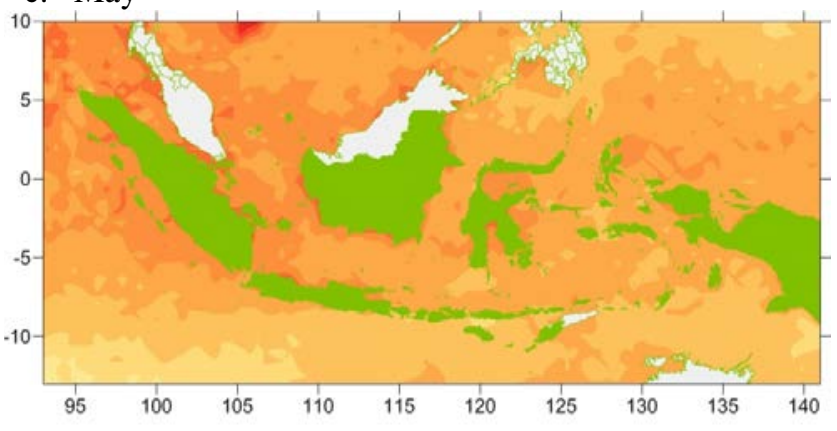

\section{Sea Surface Temperature ( $\left.{ }^{\circ} \mathrm{C}\right)$

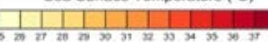 \\ Figure 5. SST in the fisrt transition season}

\section{4) The Second Transition Season}

The Second transition season is transition from east season to west season. This season shown a similar pattern to the first transitional season. The season shown in figure 6. In this season seen decreasing of SST in northern region. The decreasing of SST value in the Southern region has not been too visible by September. Because there is influence from the east season. It is indicating by its low temperature in a severals area like South Java, South Bali, South Nusa Tenggara, Arafura Sea and Banda Sea. The decrease of SST value in northern area began to be seen in October and more clearly in November.

In this season the highest temperature could reached 32 ${ }^{\circ} \mathrm{C}$ in November it seen in Timor Sea. While the lowest temperature could have reached $27^{\circ} \mathrm{C}$.

a. September
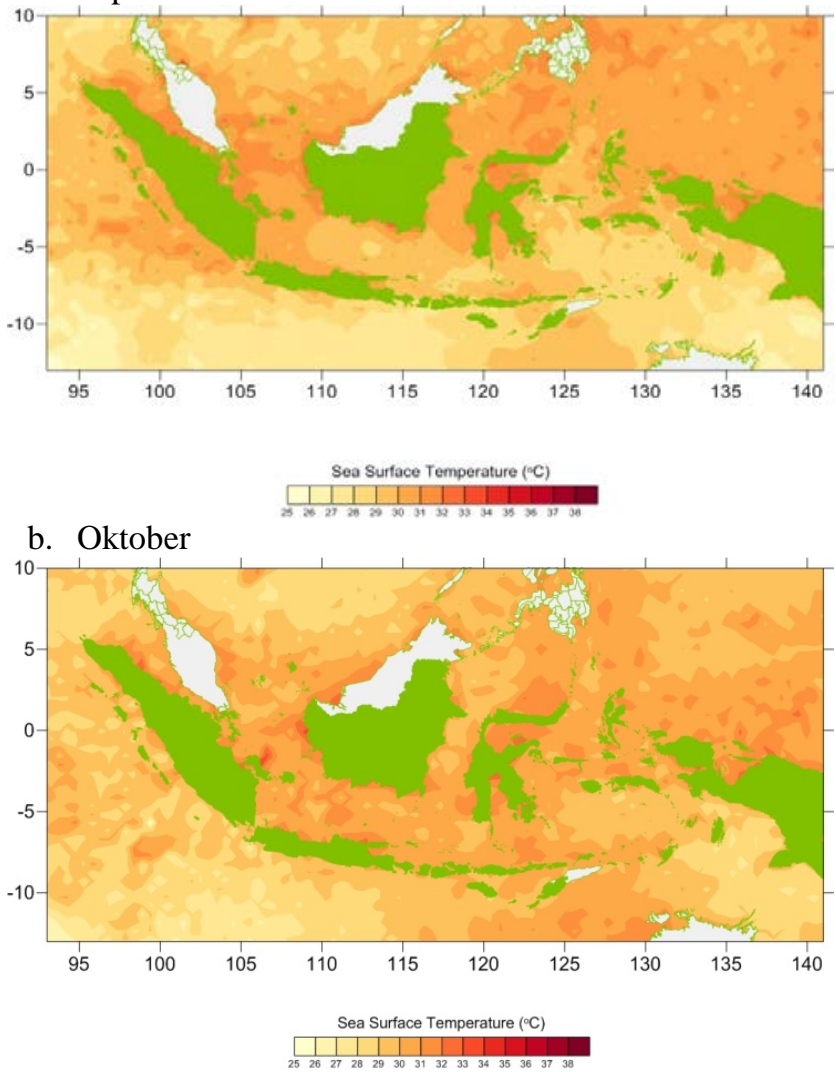


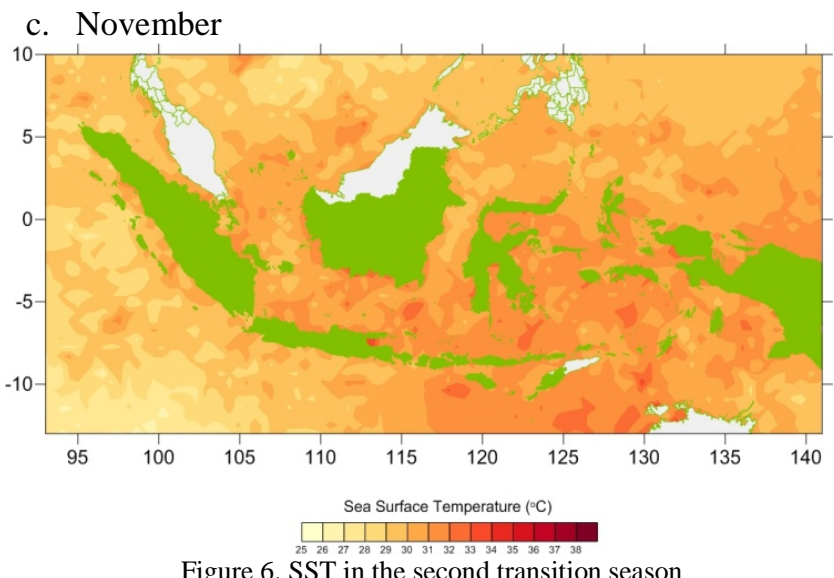

Figure 6. SST in the second transition season

\section{CONCLUSION}

Variability of Sea Surface Temperature (SST) in indonesian region dominant influence by the season. The maximum and minimum value of SST depends on certain time and location. In west season, south area of Indonesia Shown shown higher temperature than north area. and when in east season, is the opponent of west season.

\section{ACKNOWLEDGEMENT}

Authors would like to thank all the people who were involved in the programmes providing free access to the data sets used in this study. The ocean color data were made available through the National and Space Administration (NASA) Oceancolor Web (oceancolor.gsfc.nasa.gov).

\section{REFERENCE}

[1] Asian Development Bank, Indonesia Country Water assessment. Manila: Asian Development Bank, 2016.

[2] T. Qu, Y. Du, J. Stachan, G. Meyers, and J. Slingo, "Sea Surface Temperature and its Variability in the Indonesian Region," Oceanography, vol. 18, no. 4, pp. 50-61, Dec. 2005.

[3] A. Sulaiman, N. Hendiarti, F. Syamsudin, M. C. G. Frederik, Y. S. Djajadihardja, and R. Andiastuti, Riset dan Teknologi Pemantauan Dinamika Laut Indonesia. Jakarta: Ministry of Marine Affairs and Fisheries Republic of Indonesia, 2006.

[4] NASA, "MODIS (Moderate Resolution Imaging Spectroradiometer).” [Online]. Available: https://modis.gsfc.nasa.gov/.

[5] M. Tanaka, "The Onset and Retreat Dates of the Austral Summer Monsoon over Indonesia, Australia and New Guinea," J. Meteorol. Soc. Japan. Ser. II, vol. 72, no. 2, pp. 255-267, Apr. 1994.

[6] A. M. Napitu, A. L. Gordon, K. Pujiana, A. M. Napitu, A. L. Gordon, and K. Pujiana, "Intraseasonal Sea Surface Temperature Variability across the Indonesian Seas*," J. Clim., vol. 28, no. 22, pp. 8710-8727, Nov. 2015.

[7] A. Wyrtki, "Physical Oceanography of the Southeast Asian Waters," California, Jan. 1961.

[8] G. A. Meehl, "The Annual Cycle and Interannual Variability in the Tropical Pacific and Indian Ocean Regions," Mon. Weather Rev., vol. 115, no. 1, pp. 27-50, Jan. 1987. 